\title{
A revision of the Rhoptrobothriidae (Cestoda: "Tetraphyllidea")
}

\author{
KIRSTEN JENSEN ${ }^{1,3}$, ISABEL A. M. PEN ${ }^{1,4} \&$ JANINE N. CAIRA ${ }^{2}$ \\ ${ }^{1}$ Department of Ecology \& Evolutionary Biology and the Biodiversity Institute, University of Kansas, 1200 Sunnyside Ave., Lawrence, \\ KS 66045, USA. \\ ${ }^{2}$ Department of Ecology \& Evolutionary Biology, University of Connecticut, 75 N. Eagleville Rd., Storrs, CT 06269-3043, USA. \\ झ" janine.caira@uconn.edu; 이ttps://orcid.org/0000-0001-9597-6978 \\ 3 ”jensen@ku.edu; @ ittps://orcid.org/0000-0003-0294-8471 \\ "="iampen@ku.edu; ○ https://orcid.org/0000-0002-4409-8156
}

\begin{abstract}
The Rhoptrobothriidae are one of the more enigmatic families of cestodes of elasmobranchs. Opinions on the taxonomic status of the family's three original genera (i.e., Myzophyllobothrium, Rhoptrobothrium, and Myzocephalus) have varied over the 115 years since they were erected. Some authors have considered all three valid, others have considered Rhoptrobothrium to be a synonym of Myzopyllobothrium or a genus inquirendum, yet others have considered Myzocephalus to be a synonym of the phyllobothriid genus Thysanocephalum. All three genera were established for specimens collected from eagle rays off Sri Lanka. The erection of Mixophyllobothrium for two specimens from a cowtail stingray off India three decades ago added additional confusion to the situation, with some authors considering it valid and others a synonym of Myzocephalus. These disagreements stem largely from differences in interpretation of the complex morphology of the scolex of members of these genera. Furthermore, with the exception of Rhoptrobothrium comprising four species, each genus is monotypic. All but Rhoptrobothrium has not been considered in detail for nearly a century, largely because of a lack of available material. The taxonomic status of these genera is assessed here based on light and scanning electron microscopy, and molecular data generated from new material collected from eagle rays off Indonesian and Malaysian Borneo, Japan, Sri Lanka, and Viet Nam. Morphological work indicates that the genera differ largely only in the degree of folding of the four remi that extend from the cephalic peduncle. A molecular phylogeny based on sequence data for the D1-D3 region of the 28S rRNA gene, which include new data for eight specimens of four species, indicates that Myzophyllobothrium, Myzocephalus, and Rhoptrobothrium are not mutually monophyletic. The latter two genera and Mixophyllobothrium are considered synonyms of Myzophyllobothrium and five species are transferred to that genus. Myzophyllobothrium okamuri n. comb. is considered a species inquirendum. Myzophyllobothrium nagasawai n. sp. is described from Aetobatus narutobiei off Japan. Myzophyllobothrium narinari n. comb. is re-described based on newly collected cestodes from the type host and locality (i.e., Aetobatus ocellatus off Sri Lanka). Despite consisting of only a single genus, the family status of the group is retained in recognition of the unusual configuration of the scolex, which bears four biloculate bothridia and four remi extending from the cephalic peduncle. The ordinal placement of the family remains uncertain, but affinities with the Phyllobothriidea, rather than "Tetraphyllidea" are considered.
\end{abstract}

Key words: new species, Myzophyllobothrium nagasawai n. sp., Myzocephalus, Rhoptrobothrium, Rhoptrobothriidae, eagle rays

\section{Introduction}

This study aims to resolve uncertainty surrounding the identity, morphology, and validity of a poorly known assemblage of four genera of tapeworms - many of which have not been seen for nearly a century-that parasitize members of the eagle ray genera Aetobatus Blainville and Aetomylaeus Garman. These tapeworms are unique among genera parasitizing elasmobranchs in their possession of a complex structure posterior to the bothridia consisting of four extensions of the cephalic peduncle referred to as remi (Jensen and Caira 2006). Myzophyllobothrium Shipley and Hornell, 1906 is monotypic. To our knowledge, the only collection of specimens beyond the type material of Myzophyllobothrium rubrum Shipley and Hornell, 1906 collected by Shipley and Hornell (1906) from the white-spotted eagle ray, Aetobatus ocellatus (Kuhl) (as Aetobatis narinari [Euphrasen]), off Sri Lanka (as Ceylon), 
which also served as the source of the scolex illustrated by Joyeux and Baer (1961; fig. 290), is that of Southwell (1925) who reported collecting two specimens and several fragments of this species from the same host and locality in 1909. Myzocephalus narinari Shipley and Hornell, 1906, also the only member of its genus, was collected also from Aetob. ocellatus (as Aetobatis [sic] narinari) off Sri Lanka (as Ceylon) by Shipley and Hornell (1906). This genus was not reported again until almost a century later when Caira et al. (2001) included a specimen they identified as Myzocephalus sp. from Aetob. ocellatus off Australia in their morphological analysis. Caira et al. (2014) subsequently included a specimen from the same host and locality, identified as Myzocephalus sp. 1, in their molecular phylogenetic analysis. Mixophyllobothrium okamuri Shinde and Chincholikar, 1980, the only member of Mixophyllobothrium Shinde and Chincholikar, 1980, to our knowledge, has not been reported since it was described by Shinde and Chincholikar (1980) from two specimens collected from a host they identified as Trygon sephen (Fabricius) off Ratnagiri, India. Rhoptrobothrium Shipley and Hornell, 1906 is the most well-known of the four genera. This genus was established by Shipley and Hornell (1906) for Rhoptrobothrium myliobatidis Shipley and Hornell, 1906, which they collected from the mottled eagle ray, Aetomylaeus maculatus (Gray) (as Myliobatis [sic] maculata Gray), off Sri Lanka (as Ceylon). The generic diagnosis was revised by Jensen and Caira (2006) to accommodate three new species from the banded eagle ray, Aetomylaeus nichofii (Bloch and Schneider), they collected off Malaysian Borneo. In addition to sharing the presence of extensions of the cephalic peduncle called remi, which vary in width across members of these four genera, each of the four bothridia of Myzocephalus, Mixophyllobothrium, and Rhoptrobothrium were re-interpreted by Jensen and Caira (2006) to bear an anterior region in the form of a loculus followed by a single posterior loculus. However, some uncertainty remains regarding the configuration of this region of the scolex in Myzophyllobothrium. In the original description of Myzop. rubrum, Shipley and Hornell (1906) considered this region to consist of four suckers, but illustrated both a scolex with four simple suckers (their figs. 19 and 21) as well as one that appears to bear divided bothridia (their fig. 18).

Historically, opinions have differed regarding the validity of these four genera. As examples, Southwell (1925) considered Rhoptrobothrium to be a synonym of Myzophyllobothrium, and Myzocephalus to be a synonym of the phyllobothriid genus Thysanocephalum Linton, 1890. These synonymies were accepted by Wardle and McLeod (1952), Yamaguti (1959), and Schmidt (1986). Euzet (1994) considered Myzocephalus and Myzophyllobothrium to be valid, Rhoptrobothrium to be a genus inquirendum, and Mixophyllobothrium (misspelled as Myxophyllobothrium) to be a synonym of Myzocephalus. In contrast, Schmidt (1986) considered Mixophyllobothrium to be valid. Jensen and Caira (2006) followed Euzet (1994) in considering Mixophyllobothrium a synonym of Myzocephalus but considered Myzocephalus, Myzophyllobothrium, and Rhoptrobothrium as valid genera. Caira et al. (2017) also considered all three of the latter genera valid, but considered Mixophyllobothrium as incertae sedis.

Examination of new specimens of cestodes bearing remi collected from Aetob. ocellatus off Sri Lanka and Indonesian Borneo, and from the Naru eagle ray, Aetobatus narutobiei White, Furumitsu, and Yamaguchi, off Viet Nam and Japan, in combination with new molecular data for specimens spanning the range of scolex morphologies seen across these taxa, provide morphological and molecular insights that facilitate assessment of the affinities and validity of these genera at this time.

\section{Materials and methods}

\section{Specimen collection}

Cestodes were collected from one male specimen of Aetob. ocellatus (SL-2), $114 \mathrm{~cm}$ in disc width (DW), on March 08, 2018 in the Gulf of Mannar, Sri Lanka (Palkanththura landing site [08 $\left.28^{\prime} 34.36^{\prime \prime} \mathrm{N}, 79^{\circ} 51^{\prime} 45.80^{\prime \prime} \mathrm{E}\right]$, North Western Province); one female specimen of Aetob. ocellatus (KA-304), $75.4 \mathrm{~cm}$ in DW, on July 27, 2007 in the South China Sea off Indonesian Borneo (Sepuk Laut [00'12'51.60”S, $\left.109^{\circ} 05^{\prime} 00.30^{\prime \prime} \mathrm{E}\right]$, West Kalimantan); two male specimens of Aetob. narutobiei (VN-2 and VN-40) collected in the Gulf of Tonkin, Viet Nam $(59.5 \mathrm{~cm}$ in DW,

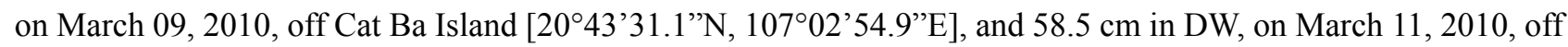
Bach Long Vi Island [ $\left.20^{\circ} 07^{\prime} 60.00^{\prime \prime} \mathrm{N}, 10^{\circ} 43^{\prime} 60.00^{\prime \prime} \mathrm{E}\right]$, respectively); one female specimen of Aetom. maculatus (BO-179), $36 \mathrm{~cm}$ in DW, on May 15, 2003 in the South China Sea off Malaysian Borneo (Sematan [01 ${ }^{\circ} 48^{\prime} 15.45^{\prime \prime} \mathrm{N}$, $\left.109^{\circ} 46^{\prime} 47.17^{\prime \prime} \mathrm{E}\right]$, Sarawak); and one female specimen of Aetom. nichofii (KA-96), $34.5 \mathrm{~cm}$ in DW, on December 02, 2006 in the Java Sea off Indonesian Borneo (Takisung [0352’28.00’'S, 114³6’37.00”E], South Kalimantan).

All specimens were collected by local fishers. In each case, the eagle ray specimen was assigned a unique speci- 
men number consisting of a collection code and collection number (i.e., SL-2), and was measured and photographed. Morphometric and additional collection data are available in the Global Cestode Database (Caira et al. 2020a) by searching by the unique specimen number. Host identifications were confirmed using NADH dehydrogenase subunit 2 (NADH2) sequence data by Naylor et al. (2012) and Fernando et al. (2019). In each case, the body cavity was opened with a midventral incision, and the spiral intestine removed and opened with a longitudinal incision. The spiral intestine was rinsed with sea water and worms encountered were saved in either $10 \%$ seawater-buffered formalin for morphological work or $95 \%$ ethanol for molecular work. The spiral intestine was subsequently fixed in $10 \%$ seawater-buffered formalin. All formalin-fixed material was transferred to $70 \%$ ethanol one to two weeks post fixation.

Specimens of the new species, which were collected June 19, 2008 from a specimen of Aetob. narutobiei of unknown sex and size from the Seto Inland Sea, Japan, were sent to us in 70\% ethanol by Kazuya Nagasawa.

\section{Morphological methods}

Cestodes from Aetob. ocellatus from Sri Lanka and Malaysian Borneo, and from Aetob. narutobiei from Japan and Viet Nam prepared was whole mounts were hydrated, stained with Delafield's hematoxylin, dehydrated in a graded ethanol series, cleared with methyl salicylate, and mounted in Canada balsam on glass slides. Scolices and proglottids of cestodes from Aetob. ocellatus from Sri Lanka and proglottids from Aetob. narutobiei from Japan prepared for histology were superficially stained in Fast Green, dehydrated in a graded ethanol series, cleared in xylene, and embedded in paraffin. Serial sections were cut at a thickness of $7 \mu \mathrm{m}$ using an Olympus Cut 4060 retracting rotary microtome (Triangle Biomedical Sciences, Durham, NC). Sections were then floated on a $2.5 \%$ sodium silicate solution on glass slides and allowed to dry on a slide warmer at $40 \mathrm{C}$. Sections were deparaffinized in xylene, hydrated in a graded ethanol series, stained with Delafield's hematoxylin, counter-stained with eosin, differentiated in Scott's solution, dehydrated in a graded ethanol series, cleared in xylene, and mounted on glass slides in Canada balsam. For preparation of semi-permanent mounts of eggs of specimens from Aetob. narutobiei from Japan, detached gravid proglottids were placed in a mixture of $70 \%$ ethanol and lactophenol (1:1) overnight to clear. Subsequently, proglottids were placed in a drop of lactophenol on a glass slide, broken open with insect pins to release the eggs, and the eggs were mounted in lactophenol under a cover slip. The cover slip was subsequently ringed twice with nail polish to seal. Specimens from Aetob. ocellatus from Sri Lanka and from Aetob. narutobiei from Japan and Viet Nam for examination with scanning electron microscopy were hydrated, transferred to $1 \%$ osmium tetroxide and left overnight at $4 \mathrm{C}$, dehydrated in a graded ethanol series, and placed in hexamethyldisilizane (HMDS, Electron Microscopy Sciences, Hatfield, PA) for $30 \mathrm{~min}$. Specimens were subsequently allowed to air-dry, mounted on aluminum stubs with double-sided adhesive carbon dots (PELCO tabs, Ted Pella, Inc., Redding, CA), sputter-coated with 30-35 nm of gold, and examined with a Hitachi S4700 field emission scanning electron microscope (Hitachi, Schaumburg, IL) at the Microscopy and Analytical Imaging Research Resource Laboratory, University of Kansas, Lawrence, Kansas. Vouchers of specimens examined as histological sections and with scanning electron microscopy (SEM) were prepared as whole mounts as described above.

Line drawings were made using a camera lucida attached to a Zeiss Axioskop 2 plus compound microscope (Zeiss, Thornwood, NY). Measurements of whole-mounted worms were taken using an Infinity 3-6URC USB camera (Teledyne Lumenera, Ottawa, Ontario, Canada) attached to the same compound microscope and the image analysis program Infinity Analyze Version 7.0.2.920 (Teledyne Lumenera). Measurements are given in micrometers $(\mu \mathrm{m})$ unless otherwise stated and are reported as ranges followed in parentheses by the mean, standard deviation, number of individual specimens examined, and the total number of measurements if measurements or more than one feature were taken per worm. Images of histological sections and eggs were taken using the camera system described above.

Microthrix terminology follows Chervy (2009). Museum abbreviations used are as follows: BRT-P, Blue Resources Trust Parasitology Collection, Kalkudah, Sri Lanka; LRP, Lawrence R. Penner Parasitology Collection, University of Connecticut, Storrs, USA; MPM, Meguro Parasitological Museum, Tokyo, Japan; USNM, National Museum of Natural History, Smithsonian Institution, Department of Invertebrate Zoology, Washington, D.C., USA.

\section{Molecular methods}

Sequence data of the D1-D3 region of the $28 S$ rRNA gene (hereafter 28S) were generated de novo for eight speci- 
mens. Based on their original generic assignments, these consisted of three specimens of Myzoc. narinari, two that were collected from the type host (Aetob. ocellatus) and type locality (Sri Lanka) and one that was collected from Aetob. ocellatus off Indonesian Borneo; two specimens superficially resembling Myzop. rubrum from Aetob. narutobiei in Viet Nam; one specimen of Rhoptrobothrium gambangi from Aetom. nichofii off Indonesian Borneo; and two specimens of R. myliobatidis from the type host Aetom. maculatus off Malaysian Borneo. In each case, genomic DNA was extracted from the middle or posterior portions of the strobila, and the remainder of each specimen (i.e., hologenophore sensu Pleijel et al. 2008) was prepared as a whole mount and deposited in the LRP.

Sequencing methods differed across specimens. For the three specimens of Myzoc. narinari, 28S sequence data were generated using Sanger sequencing. Genomic DNA was extracted from the middle or posterior portions of the strobila using a MasterPure Complete DNA and RNA Purification Kit (Epicentre Biotechnologies, Madison, WI) and eluded in $60 \mu \mathrm{TE}$ buffer. For two of these specimens, 28S was amplified using illustra PuReTaq Ready-To-Go PCR beads (GE Healthcare, Chicago, IL) using the primers ZX-1 (5'-ACCCGCTGAATTTAAGCATAT-3') (modified from van der Auwera et al. 1994) and 1500R (5'-GCTATCCTGAGGGAAACTTCG-3') (Olson et al. 2003; Tkach et al. 2003) and the following thermocycler temperature profile: denaturation for $2 \mathrm{~min}$ at $94 \mathrm{C}$, followed by 40 cycles of $30 \mathrm{sec}$ at $94 \mathrm{C}, 30 \mathrm{sec}$ at $55 \mathrm{C}$, and $2 \mathrm{~min}$ at $72 \mathrm{C}$, and elongation for $10 \mathrm{~min}$ at $72 \mathrm{C}$. Unpurified PCR product was sequenced by GENEWIZ (South Plainfield, NJ) using single pass primer extension and PCR primers. For the remaining specimen, amplification, purification, sequencing followed Caira et al. (2020b). Contigs were assembled using Geneious Prime 2019 (Biomatters, Inc., San Diego, CA). Data for this same region for the remaining five specimens (i.e., the two specimens from Viet Nam resembling Myzop. rubrum, the specimen of R. gambangi, and the two specimens of $R$. myliobatidis) were generated and assembled by Hannah Ralicki and Elizabeth Jockusch using MITObim version 1.9.1 (Hahn et al. 2013) from Next Generation Sequencing reads for a related project.

Sequence data for the above eight specimens of four species were combined with sequence data for the two specimens of rhoptrobothriids, both from Caira et al. (2014), available in GenBank. Based on their original identifications, these are $R$. cf. gambangi (KF685774) from Stegostoma fasciatum (Hermann) (BO-492) off Malaysian Borneo and Myzocephalus sp. 1 (KF685887) from Aetob. ocellatus (AU-41) off Australia. The phyllobothriideans Yamaguticestus cf. squali (KF685897 from Caira et al. 2014 [as Phyllobothrium cf. squali]; see also Caira et al. 2021) and Clistobothrium gabywalterorum Caira, Hayes, and Jensen, 2020 (MN706183 from Caira et al. 2020c) were used as outgroups. Sequence alignment and phylogenetic methods follow Caira et al. (2020c). Based on sample size corrected Akaike Information Criterion values used to evaluate goodness of fit generated with jModelTest (Guindon and Gascuel 2003; Darriba et al. 2012), TVM \pm I was used as the model of evolution.

\section{Results}

\section{Phylogenetic analysis}

28S sequence data generated for this study have been deposited in GenBank (MZ189002-MZ189009). The sequence alignment obtained using PRANK (Löytynoja and Goldman 2010) was 1,441 bp in length, with the ingroup taxa ranging in alignment length from 1,342 to $1,441 \mathrm{bp}$. The tree resulting from our phylogenetic analysis is shown in Figure 1. Taxon labels for the rhoptrobothriids include our proposed revised generic assignment and the original generic assignment in parentheses. In the cases of the two specimens for which data were obtained from GenBank, the specific identification has also been revised.

Monophyly of the family, as represented by Rhoptrobothrium cf. gambangi and Myzocephalus sp., was robustly established in the analyses of Caira et al. (2014) based on 18S and partial 28S sequence data in a comprehensive framework of elasmobranch-hosted tapeworms. The focus of the phylogenetic analysis conducted here was the relationships of taxa within the Rhoptrobothriidae. This phylogeny suggests that revision of generic assignments is required if generic monophyly is to be achieved. The three species of Rhoptrobothrium do not form a monophyletic group relative to the specimens of Myzocephalus and those resembling Myzophyllobothrium. A clade consisting of the specimens of $R$. gambangi and $R$. limae groups as the sister taxon to a clade consisting of the specimens of Myzocephalus and those resembling Myzophyllobothrium; R. myliobatidis is their sister taxon. To preserve generic monophyly, given the morphology of the taxa involved, the most conservative approach is to synonymize all three genera. Since all three names were established by Shipley and Hornell (1906) in the same paper, the principle of priority (ICZN Article 23.1; ICZN, 1999) does not inform the appropriate nomenclatorial decision in this case. Given that Southwell (1925) considered Rhoptrobothrium to be a synonym of Myzophyllobothrium we accept the latter as 
the valid generic name of the genus based on the Principle of the First Reviser (ICZN Article 24.2.2; ICZN, 1999). Myzocephalus and Rhoptrobothrium are thus considered synonyms of Myzophyllobothrium here. Following Euzet (1994), so too is Mixophyllobothrium. However, the identity of its only species, Mixop. okamuri, remains in doubt. Myzophyllobothrium okamuri (Shinde and Chincholikar, 1980) n. comb. is considered as a species inquirendum. Based on the information provided by Shinde and Chincholikar (1980), it is possible this is a synonym of Myzop. narinari, but this possibility was not addressed at the time of the description. The identity of the type host, Pastinachus ater (Mcleay) (as Trygon sephen), the only member of Pastinachus Rüppell that occurs on the western coast of India (see Last et al. 2016), is also highly questionable. This is not only because all other rhoptrobothriids-with the exception of what we believe is an accidental infection in Stegostoma fasciatum (see discussion) - parasitize members of the families Aetobatidae Agassiz or Myliobatidae Bonaparte, rather than the Dasyatidae, but also because a substantial amount of work has been done on the cestodes of Pastinachus (e.g., Verma 1928; Southwell 1929; Baer and Euzet 1962; Deshmukh 1979; Shinde and Deshmukh 1979; Hassan 1983; Beveridge 1990; Campbell and Beveridge 2002; Jensen and Caira 2008; Kuchta and Caira 2010, Zschoche et al. 2011; Schaeffner and Beveridge 2012, 2013; Haseli 2013; Maleki et al. 2013, 2018; Haseli and Palm 2015; Reyda et al. 2016; Roohi Aminjan and Malek 2017; Coleman et al. 2019), none of which has yielded rhoptrobothriid specimens. A revised diagnosis for Myzophyllobothrium that accommodates these synonymies is provided below.

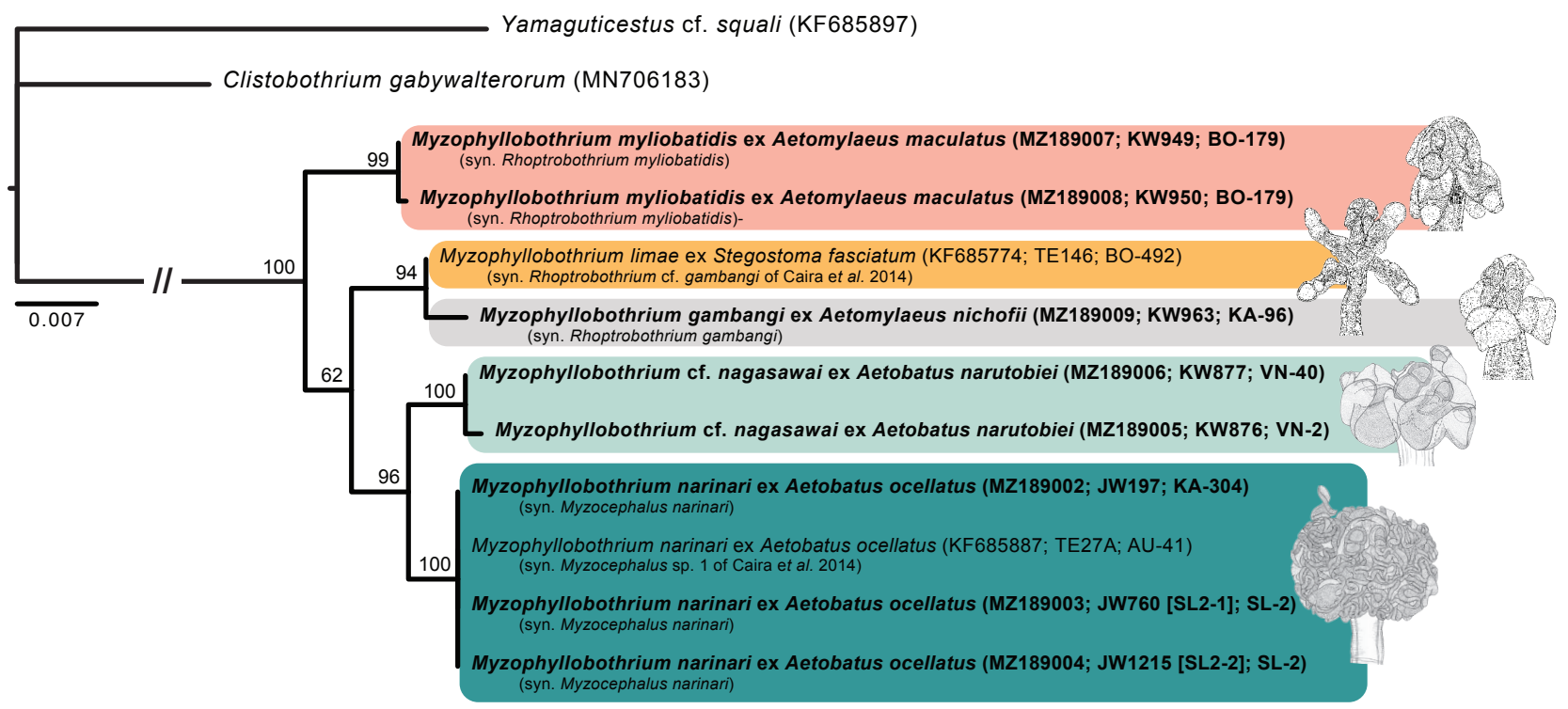

FIGURE 1. Phylogenetic tree showing the interrelationships of the Rhoptrobothriidae based on maximum likelihood analysis of the D1-D3 region of the 28S rRNA gene. Nodal support, given as bootstrap values, is indicated above the branches. Specimens for which sequence data were generated de novo are indicated in bold. Taxon labels for the Rhoptrobothriidae consist of cestode species name with proposed revised generic assignment and host species name, followed by the GenBank accession number, specimen number, and host number; species names with original generic assignments and original identifications are given in parentheses below each taxon label. Scale bar indicates number of nucleotide substitutions per site.

\section{Myzophyllobothrium Shipley and Hornell, 1906}

(Syns. Mixophyllobothrium Shinde and Chincholikar, 1980; Myzocephalus Shipley and Hornell, 1906; Rhoptrobothrium Shipley and Hornell, 1906)

Generic diagnosis. Rhoptrobothriidae. Worms euapolytic. Scolex with four acetabula and cephalic peduncle. Acetabulum bothridiate in form, with two loculi; anterior loculus undivided, with or without postero-lateral extensions; posterior loculus undivided. Cephalic peduncle bearing four stalked remi; remus with terminal primary areola, with or without subterminal secondary areola. Neck absent. Proglottids craspedote or acraspedote. Testes numerous, anterior to ovary or ovarian bridge, arranged essentially in single dorso-ventral layer. Vas deferens coiled, medial to cirrus sac. Cirrus sac pyriform, containing coiled cirrus. Cirrus armed with spinitriches. Ovary H-shaped in frontal 
view, tetralobed in cross section. Vagina weakly sinuous, opening into genital atrium anterior to cirrus sac; vaginal sphincter absent. Genital pores lateral, irregularly alternating. Uterus medial, saccate, extending to cirrus sac. Vitellarium follicular; follicles arranged in two lateral bands; each band consisting of one to many columns of follicles, extending entire length of proglottid, may be interrupted by ovary. Parasites of Aetobatidae and Myliobatidae. Indian and western Pacific Oceans.

Type species: Myzophyllobothrium rubrum Shipley and Hornell, 1906.

Additional species: Myzophyllobothrium chongi (Jensen and Caira, 2006) n. comb., Myzophyllobothrium gambangi (Jensen and Caira, 2006) n. comb., Myzophyllobothrium limae (Jensen and Caira, 2006) n. comb., Myzophyllobothrium myliobatidis (Shipley and Hornell, 1906) Southwell, 1925, Myzophyllobothrium nagasawai n. sp., and Myzophyllobothrium narinari (Shipley and Hornell, 1906) n. comb.

Species inquirendum: Myzophyllobothrium okamuri (Shinde and Chincholikar, 1980) n. comb.

Remarks. The synonymization of Mixophyllobothrium, Myzocephalus, and Rhoptrobothrium with Myzophyllobothrium is supported by both morphological and molecular criteria. With respect to morphology, although the original descriptions suggest that the scolices of these genera differ dramatically from one another, examination of material of $M$. narinari and $M$. nagasawai $\mathbf{n}$. sp., the latter of which most closely resembles $M$. rubrum, with light and scanning electron microscopy reveals fundamental commonalities across these taxa. All bear a scolex that consists of four bothridia each of which bears an anterior and a posterior loculus, giving the bothridia a biloculate appearance. Although Myzophyllobothrium was described as possessing "four almost terminal suckers" (Shipley and Hornell 1906; pg. 48), the biloculate appearance of the bothridia was illustrated in their fig. 18 and was confirmed by Joyeux and Baer (1961; fig. 290) after examination of a co-type specimen of M. rubrum. The remaining differences are in the four remi that extend from the cephalic peduncle posterior to the bothridia. However, these differences can be considered to be essentially just variations in the width and extent of folding of the remi. In M. narinari and M. rubrum the remi are either much wider than, or nearly as wide as, they are long; in all four species formerly assigned to Rhoptrobothrium, the remi are longer than wide. The remi of M. narinari are highly folded; those of M. rubrum and M. nagasawai n. sp. are less folded; in all four species formerly assigned to Rhoptrobothrium, the remi are weakly or essentially unfolded. These taxa also share a number of notable similarities in proglottid anatomy. In all seven valid species, the cirrus sac is relatively large, extending to the midline of the proglottid, and is located near the middle of the proglottid. All species also possess a post-poral field of testes and a uterus that extends anteriorly in mature proglottids only to the level of the cirrus sac. In all species, the ovary is lobulated, H-shaped in frontal view, and tetralobed in cross section. The main differences among species are in testes number, number of columns of vitelline follicles, and whether the columns are interrupted by the ovary. The microthrix patterns on the scolices of the six species that have been examined with SEM are also very consistent. Little variation exists across surfaces of the scolex; all surfaces of the scolex of all species bear small, slender gladiate spinitriches and capilliform filitriches, albeit of varying relative densities.

The terminology we have applied here to the configuration of the bothridial portion of the scolex differs from that used by Jensen and Caira (2006) for species of Rhoptrobothrium. These authors followed the terminology of Caira et al. (1999; 2001) and described the bothridia (e.g., Jensen and Caira, 2006, pg. 191) as bearing a "specialized anterior region in form of loculus and undivided main loculus". This terminology was employed to reflect the homology of the different regions of the bothridia of these species with those of other genera. For clarity, we have simplified this terminology here and refer to the bothridia as bearing an anterior and a posterior loculus (i.e., biloculate bothridia). The homologies described by Jensen and Caira (2006) stand; but this revised terminology simplifies comparisons with previous descriptions of members of this group.

Among the 21 valid genera of phyllobothriideans (see Ruhnke et al. 2017; Caira et al. 2021), Myzophyllobothrium most closely resembles Ruhnkebothrium Caira, Bueno, and Jensen, 2021 and Thysanocephalum. All three genera appear to exhibit a scolex that is divided into two regions - a narrow anterior region bearing four biloculate bothridia and an extensive, often convoluted, posterior region, that also is divided into four parts (see Linton 1892, Caira et al. 2021). These similarities are, however, superficial. In Thysanocephalum and Ruhnkebothrium, the scolex has been determined to consist of four bothridia each of which bears a single loculus at its narrow anterior end and an extensive, convoluted posterior loculus (Caira et al. 1999, 2021, respectively). In contrast, the four biloculate bothridia of Myzophyllobothrium are completely independent structures from the remi, which are extensions of the cephalic peduncle (see Jensen and Caira, 2006 and Fig. 4C). The independence of these three genera from one another was also supported by the results of the molecular phylogenetic analysis of Caira et al. (2014) in which the representatives of Thysanocephalum, Ruhnkebothrium (referred to as New genus 10), and Myzophyllobothrium (referred to as Rhoptrobothrium and Myzocephalus) grouped with other taxa in different parts of the tree. 
Type and only known host: Whitespotted eagle ray, Aetobatus ocellatus (as Aetobatis [sic] narinari) (Myliobatiformes: Aetobatidae).

Type locality: Puttalam Lake, Sri Lanka (as Ceylon).

Additional localities: None.

Site of infection: Spiral intestine.

Specimens examined: BMNH nos. 2006.7.14.1-3, three slides identified by Southwell (1925) as Myzophyllobothrium rubrum (see Jensen and Caira 2006).

Sequence data: None.

Remarks. Joyeux and Baer (1961) resolved the issue surrounding the two different interpretations of the scolex of this species presented by Shipley and Hornell (1906). In their figure of the scolex of one of the co-types of the species, Joyeux and Baer (1961; fig. 290) illustrated the anterior region of the scolex to clearly consist of four biloculate bothridia rather than four simple suckers. Unfortunately, we have been unable to locate the co-types of this species. The specimens of M. rubrum on the three slides examined here were reported by Southwell (1925) as having been collected from the type host and locality. Unfortunately, all of these specimens are in relatively poor condition, and include only one scolex. We did not consider this material to be of sufficient quality to allow re-description of this species. Nonetheless, given the paucity of information available on the proglottid anatomy of M. rubrum, a photograph of the posterior region of a mature proglottid of one of these specimens is presented in Fig. 4A.

\section{Myzophyllobothrium narinari (Shipley and Hornell, 1906) n. comb.}

(Figs. 2A-C, 3, 4B-E)

(Syn. Myzocephalus narinari Shipley and Hornell, 1906; Myzocephalus sp. 1 of Caira et al. 2014).

Type and only known host: Whitespotted eagle ray, Aetobatus ocellatus (as Aetobatis [sic] narinari) (Myliobatiformes: Aetobatidae).

Type locality: Dutch Bay, Sri Lanka (as Ceylon).

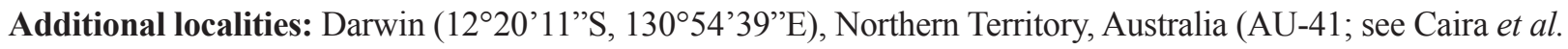
2001, 2014); Sepuk Laut (00²'51.60”S, $109^{\circ} 05^{\prime} 00.30^{\prime \prime}$ ), West Kalimantan, South China Sea, Indonesian Borneo (KA-304).

Site of infection: Spiral intestine.

Specimens deposited: Two mature worms (BRT-P nos. 004 and 005); five mature worms (USNM nos. 16559021655906), scolex longitudinal (USNM no. 1655908) and cross-section series (USNM no. 1655907), and proglottid cross-section series (USNM no. 1655909); five mature worms (LRP nos. 10336-10340), scolex longitudinal section series (LRP nos. 10341-10346), and two SEM strobilar vouchers (LRP nos. 10347 and 10348); scolices examined with SEM retained with KJ at the University of Kansas.

Sequence data: KF685887 (hologenophore, LRP no. 8280) ex Aetobatus ocellatus (AU-41) of Caira et al. (2014) (as Myzocephalus sp. 1); MZ189003 and MZ189004 (hologenophores, LRP nos. 10349 and 10350, respectively) ex Aetobatus ocellatus (SL-2); MZ189002 (hologenophore, LRP no. 10361) ex Aetobatus ocellatus (KA-304).

Re-description. Based on 12 whole mature worms, cross-section series of one scolex, longitudinal-section series of two scolices, one cross-section series of mature proglottids, and two scolices examined with SEM).

Worms euapolytic, slightly craspedote, $10.1-19.7(14.9 \pm 3 ; 12) \mathrm{mm}$ long; proglottids $72-113(93 \pm 13 ; 12)$ in total number; maximum width at level of scolex (Fig. 2B). Scolex globular (Figs. 2A, 3A), 748-1,103 (926 \pm 113.1 ; 9) long, 961-1,532 $(1,247 \pm 179.3 ; 12)$ wide, consisting of four acetabula and cephalic peduncle. Scolex proper $350-502(426 \pm 49.7 ; 12)$ wide. Acetabulum bothridiate in form, 200-294 $(247 \pm 30.6 ; 6 ; 10)$ long, biloculate, sessile anteriorly, free posteriorly; anterior loculus undivided, 81-120 (100 $\pm 11.5 ; 10 ; 20)$ long, 100-160 (130 \pm 13.0 ; 10 ; 24) wide, without postero-lateral extensions; posterior loculus undivided, 100-197 (149 \pm 25.8 ; 7; 11) long, 88-156 (122 $\pm 20.1 ; 9 ; 13)$ wide. Cephalic peduncle bearing four stalked remi (Figs. 3B, 4C); region between bothridia and remi, and region posterior to remi short; stalk short; remus voluminous (Fig. 3A, B), highly folded, wider than long, tapering terminally, with terminal primary areola (Fig. 2A, 3A, B); primary areola 56-99 (78 \pm 13.6 ; 8; 11) long, 84-124 (104 $\pm 13.0 ; 6 ; 8)$; subterminal secondary areola not observed. Neck absent. 

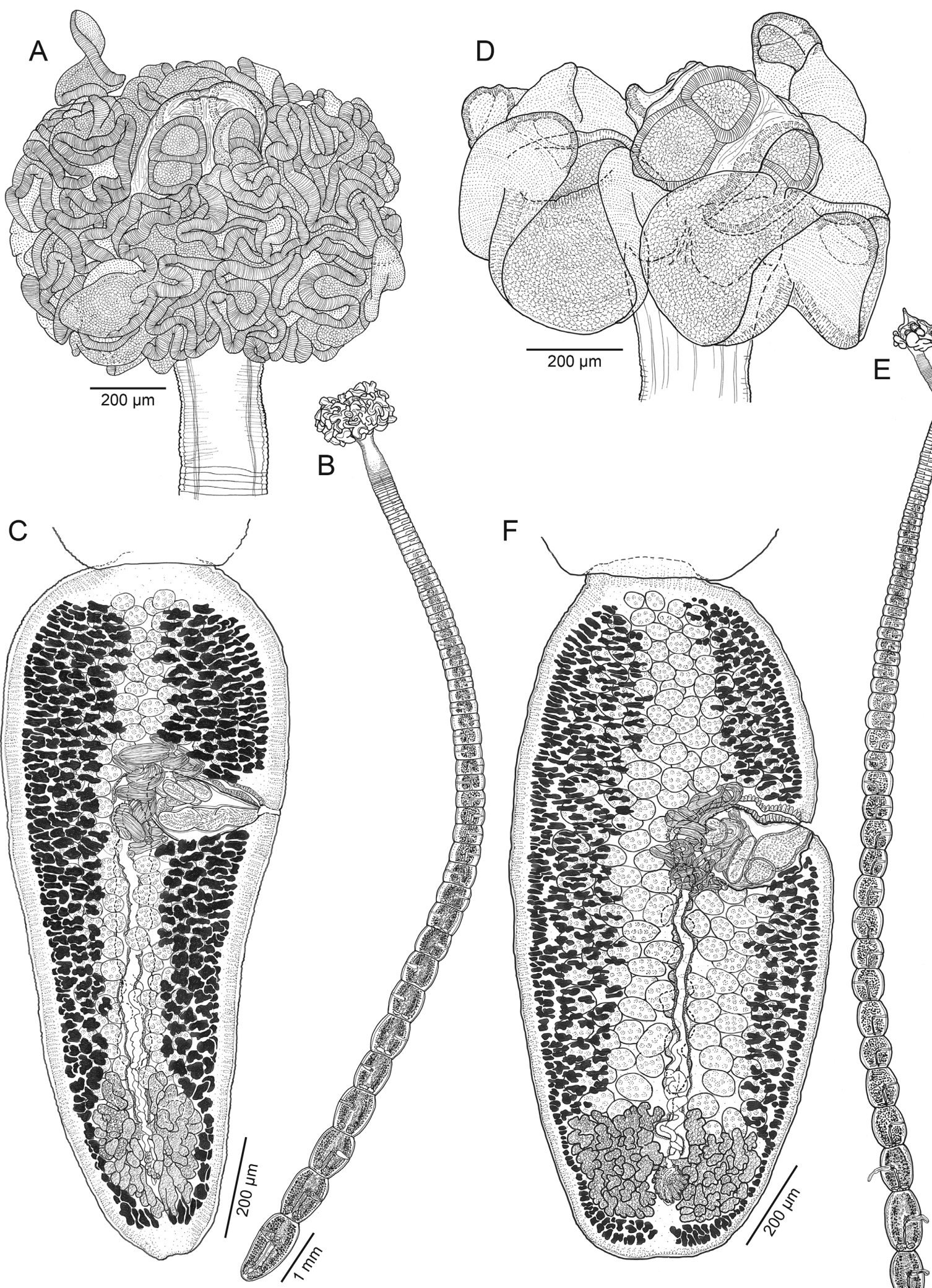

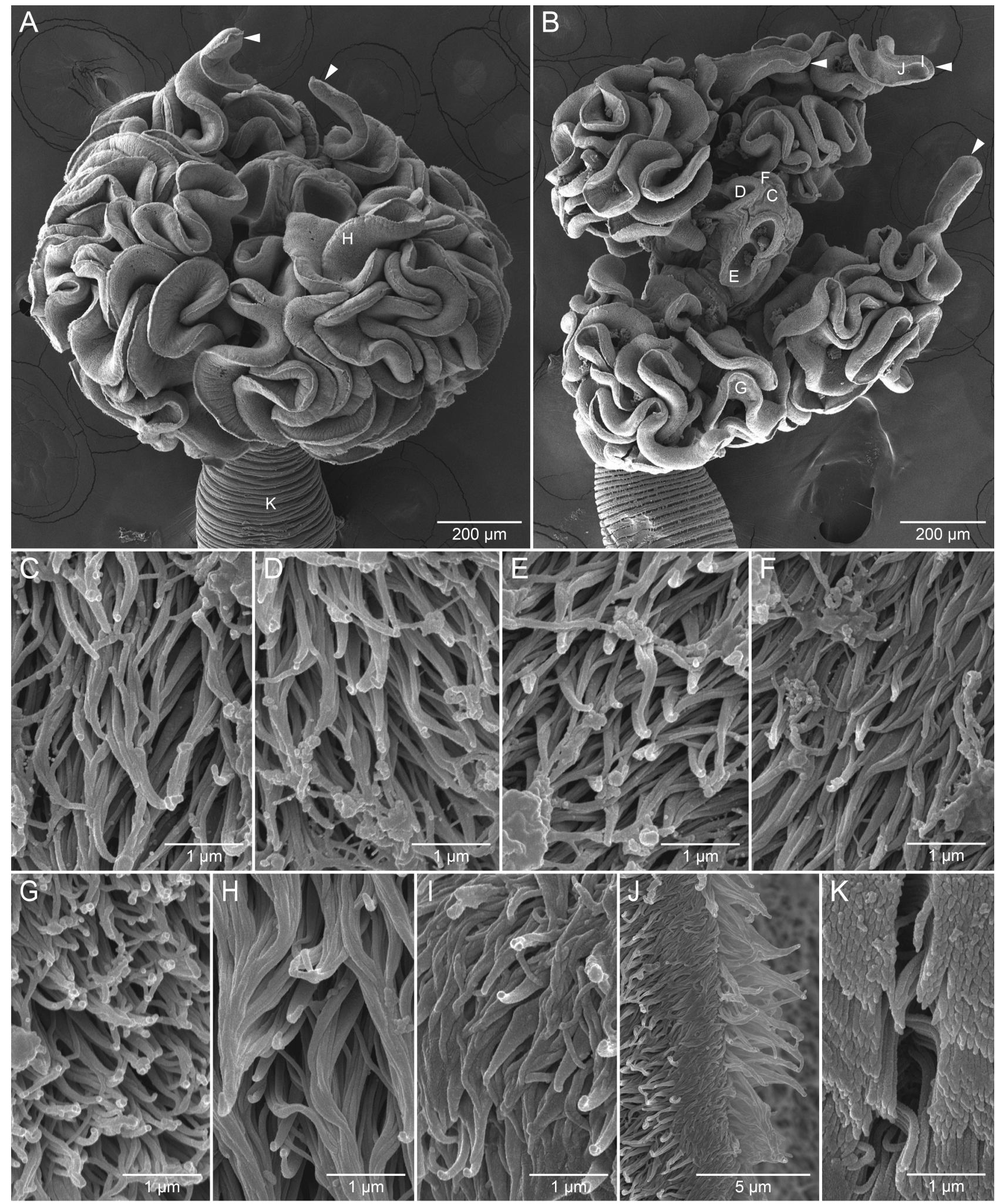

FIGURE 3. Scanning electron micrographs of Myzophyllobothrium narinari n. comb. from Aetobatus ocellatus from Sri Lanka. A. Scolex; small letters indicate locations of details in $\mathrm{H}$ and $\mathrm{K}$; arrowheads point to primary areolae. B. Scolex showing biloculate bothridia and four remi; small letters indicate locations of details in $\mathrm{C}-\mathrm{G}$, I, and J; arrowheads point to primary areolae. C. Surface of scolex proper. D. Distal surface of anterior loculus. E. Distal surface of posterior loculus. F. Proximal surface of posterior loculus. G. Distal surface of remus. H. Proximal surface of remus. I. Proximal surface of primary areola. J. Rim of remus. K. Strobilar surface. 
Apex of scolex proper (Fig. 3C), distal surface of anterior loculus (Fig. 3D) and posterior loculus (Fig. 3E), proximal surface of anterior loculus and posterior loculus (Fig. 3F), distal (Fig. 3G) and proximal (Fig. 3H) surfaces of remus, and distal surface of primary areola covered with slender gladiate spinitriches and capilliform filitriches of varying densities; proximal surface of primary areola (Fig. 3I) covered with slender gladiate spinitriches and shorter capilliform filitriches; capilliform filitriches on rims of bothridia and remi conspicuous (Fig. 3J). Strobila covered with capilliform filitriches (Fig. 3K).

Immature proglottids wider than long, becoming slightly longer than wide with maturity (Fig. 2B), 66-107 $(87 \pm 12 ; 12)$ in number; last immature proglottid 368-732 $(550 \pm 109.1 ; 12)$ long, 390-648 $(519 \pm 74.6$; 12) wide. Mature proglottids becoming longer than wide posteriorly (Fig. 2C), 2-6 $(4 \pm 1 ; 12)$ in number; terminal mature proglottid 1,010-1,600 $(1,222 \pm 180.1 ; 10)$ long, 360-649 $(486 \pm 103.2 ; 10)$ wide, length to width ratio $1.7-3.5$ $(2.6 \pm 0.5 ; 10): 1$. Gravid proglottids not observed. Testes in field extending from anterior margin of proglottid to ovarian bridge, arranged in multiple columns, one irregular layer deep in cross section (Fig. 4D), 98-167 (133 \pm 18 ; $12 ; 32)$ in total number, $21-38(30 \pm 4 ; 12 ; 32)$ in number in post-poral field, $19-41(30 \pm 5.4 ; 12 ; 36)$ long, $32-68$ $(50 \pm 8.2 ; 12 ; 36)$ wide. Vas deferens coiled, essentially medial to cirrus sac. Cirrus sac pyriform, $155-267(211 \pm$ 31.4 ; 12) long, 108-160 (134 $\pm 18.9 ; 12)$ wide, thin-walled, containing coiled cirrus; cirrus armed with spinitriches. Genital pores irregularly alternating, $58-66 \%(62 \pm 2.6 ; 10)$ of proglottid length from posterior end; genital atrium shallow. Vagina sinuous, extending from ootype along midline of proglottid, opening into common genital atrium anterior to cirrus sac. Ovary at posterior margin of proglottid, H-shaped in frontal view, 177-302 $(232 \pm 45.7 ; 10)$ long, 165-315 (229 \pm 49.9 ; 10) wide, tetralobed in cross section (Fig. 4E); ovarian margins lobulated. Vitellarium follicular; follicles $12-43(27 \pm 6.9 ; 12 ; 36)$ long, $28-65(46 \pm 8.5 ; 12 ; 36)$ wide, arranged in two lateral bands; each band consisting of multiple irregular columns of follicles, encroaching in midline of proglottid, extending throughout length of proglottid, interrupted by terminal genitalia, uninterrupted by ovary. Uterus ventral, medial, extending from ootype region to level of cirrus sac; uterine duct sinuous, entering uterus at midpoint. Excretory vessels four, arranged in one dorsal and one ventral pair on each lateral margin of proglottid.

Remarks. We have been unable to locate the type specimens of this species. Although this species is clearly recognizable based on the original description of the scolex and accompanying illustrations by Shipley and Hornell (1906), these authors were unable to provide a detailed description of the proglottid anatomy due to limitations of the material at hand, and thus presented only measurements of the main features of the species (total length, scolex width, and mature proglottid width). The specimens on which this re-description is based are generally consistent with the original description, however, they are smaller in several respects than those described by Shipley and Hornell (1906) (10.1-19.7 vs. $25 \mathrm{~mm}$ in total length; $748-1,103$ vs. $2 \mathrm{~mm}$ in scolex width; $360-649$ vs. $1 \mathrm{~mm}$ in terminal proglottid width). Nonetheless, given this material came from the type host near the type locality, we have little doubt about its conspecificity with $M$. narinari and attribute the differences observed to intraspecific variation, or differences in fixation and/or variation in measurements taken from live versus preserved material. This re-description expands the concept of this species of Shipley and Hornell (1906) to include new information on scolex morphology. These authors (pg. 47) described this species to bear "four slipper shaped bothridia each divided by a horizontal ridge into two areolas" and a "ruff formed of four immensely crumpled lateral extensions". After viewing these highly mobile portions of the scolex in live worms, they contemplated whether this worm exhibited "a double set of bothridia". The terminology of their otherwise highly accurate account of the scolex of this species is revised here such that the lateral extensions are referred to as remi as defined by Jensen and Caira (2006). Histological sections (Fig. 4B) confirm that these represent extensions of the cephalic peduncle separate from the bothridia. In addition, as seen in other members of the genus, each of the bothridia of this species was found to bear a terminal primary areola. The re-description also provides the first detailed information on the proglottid anatomy and the microthrix pattern of this species.

Myzophyllobothrium narinari differs from M. rubrum, M. chongi, M. gambangi, M. limae, and M. myliobatidis in possessing remi that are highly folded, rather than moderately or weakly folded. In addition, it is a smaller worm than M. rubrum (10.1-19.7 vs. $80 \mathrm{~mm}$ in total length [TL]). It is a larger worm than M. chongi, M. gambangi, M. limae, and M. myliobatidis (10.1-19.7 vs. 1.4-1.8, 1.1-2.1, 2.4-5, 1.4-3.4 mm in TL, respectively), with a greater number of testes (98-167 vs. 22-37, 22-36, 28-43, and 27-38, respectively). This is the species referred to by Caira et al. (2014) in their molecular phylogenetic analysis and in GenBank (KF685887) as Myzocephalus sp. 1.

Although not included in the re-description, specimens of this species collected from the type host off West Kalimantan on the island of Borneo (GenBank no. MZ189002) and off the Northern Territory in Australia (KF685887) 
were included in our phylogenetic analysis. Despite slight differences in morphology (e.g., total length and scolex size) these specimens were found to be identical in sequence for $28 \mathrm{~S}$ and are considered herein to be conspecific with the specimens of M. narinari from the type locality of Sri Lanka.
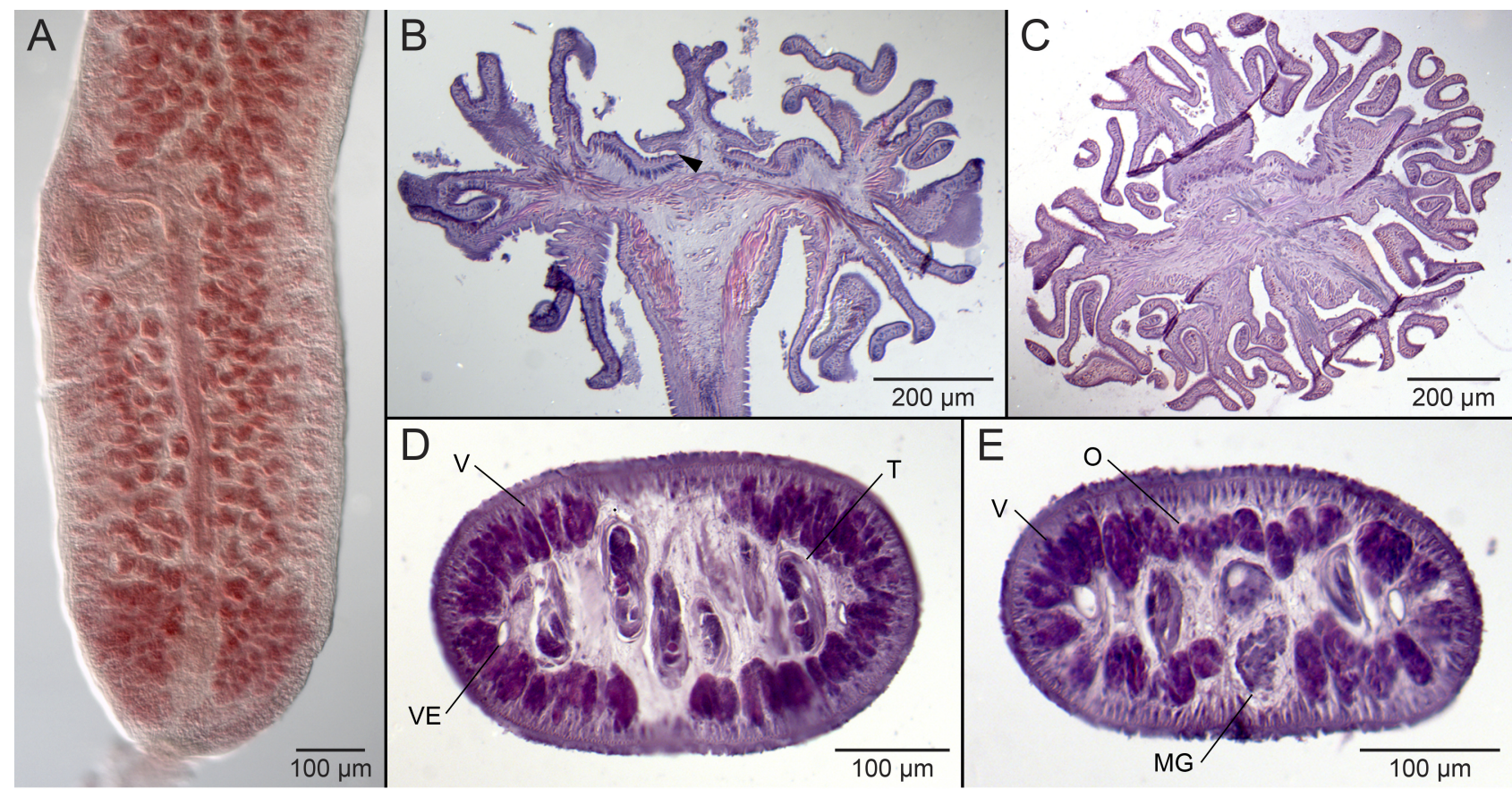

FIGURE 4. Photomicrographs of Myzophyllobothrium rubrum Shipley and Hornell, 1906 from Aetobatus ocellatus from Sri Lanka (A) and Myzophyllobothrium narinari (Shipley and Hornell, 1906) n. comb. from Aetobatus ocellatus from Sri Lanka (B-E). A. Posterior region of mature proglottid (BMNH nos. 2006.7.14.1-3) of voucher specimen of M. rubrum from Southwell (1925). B. Longitudinal section through scolex of $M$. narinari; arrowhead points to region of cephalic peduncle between bothridia from remi. C. Cross section through scolex of $M$. narinari at level of remi posterior to bothridia. D. Cross section through mature proglottid of M. narinari at level of anterior to cirrus sac. E. Cross section through mature proglottid of M. narinari at level of ovary anterior to ovarian bridge. Abbreviations: MG, Mehlis' gland; O, ovary; T, testes; V, vitelline follicles; VE, ventral excretory vessel.

\section{Myzophyllobothrium nagasawai n. sp.}

(Figs. 2D-F, 5A-M, 6)

urn:lsid:zoobank.org:act:930A6E47-571D-411F-9377-2DD6E8351AE1

Type and only known host: Naru eagle ray, Aetobatus narutobiei (Myliobatiformes: Aetobatidae).

Type locality: Seto Inland Sea, Japan.

Site of infection: Spiral intestine.

Type specimens: Holotype (complete mature worm; MPM no. 21757) and four paratypes (one incomplete mature worm, one detached pre-gravid proglottid, and one detached gravid proglottid [MPM no. 21758], and one egg preparation [MPM no. 21759]); six paratypes (three complete mature worms [USNM nos. 1655910-1655912], two detached gravid proglottids [USNM nos. 1655913 and 1655914], and one proglottid cross-section series [USNM no. 1655915]); five paratypes (two complete mature worms [LRP nos. 10351 and 10352], two detached gravid proglottids [LRP nos. 10353 and 10354], and one proglottid cross-section series [LRP nos. 10355-10358]) and two SEM strobilar vouchers (LRP nos. 10359 and 10360); two scolices and one gravid proglottid examined with SEM retained with $\mathrm{KJ}$ at the University of Kansas.

Sequence data: None.

Etymology: This species is named in honor of Kazuya Nagasawa of Hiroshima University, Japan, for his contributions to marine parasitology and for collecting the specimens on which this description was based. 

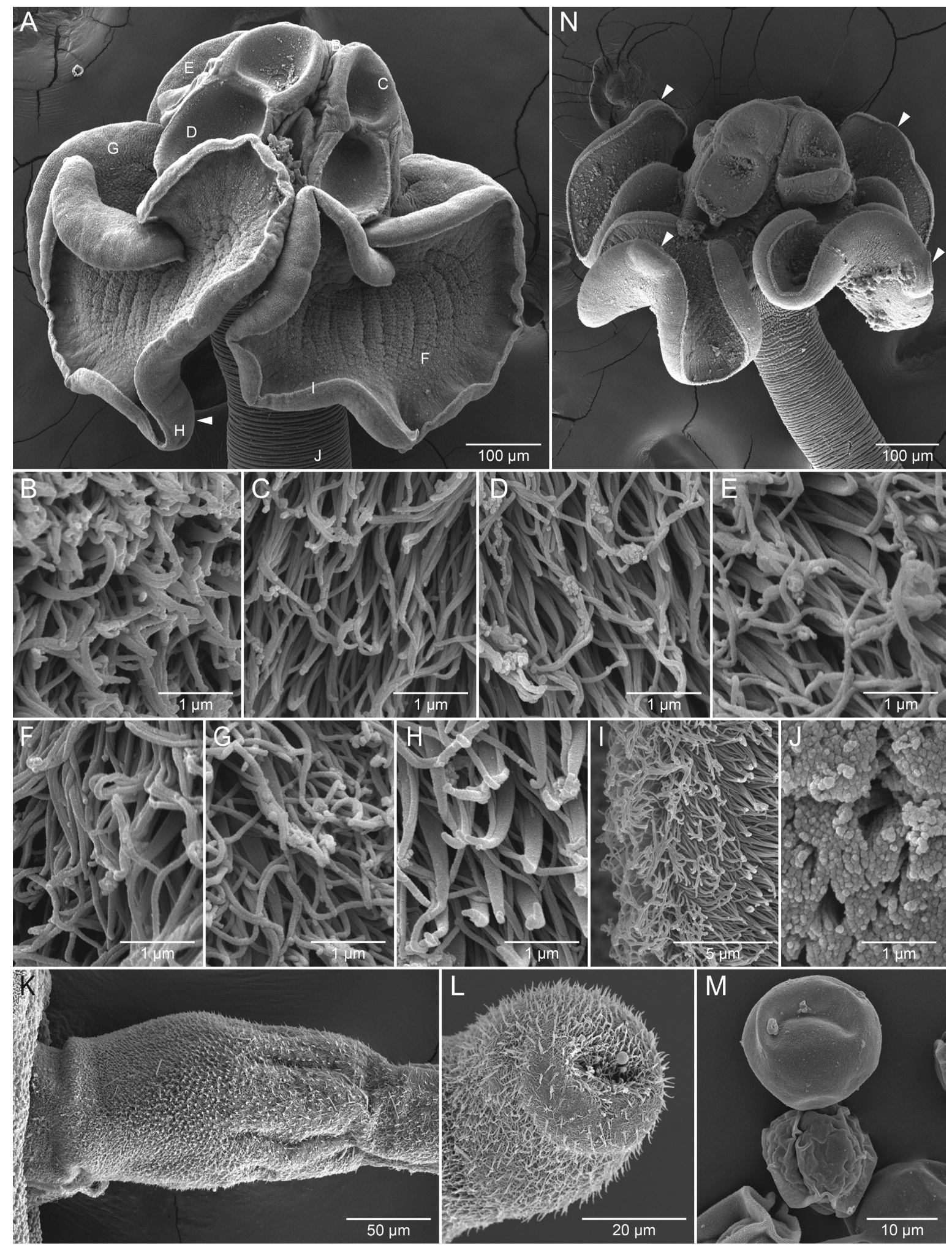

FIGURE 5. Scanning electron micrographs of Myzophyllobothrium nagasawai n. sp. from Aetobatus narutobiei from Japan (A-M) and of Myzophyllobothrium cf. nagasawai from Aetobatus narutobiei from Viet Nam (N). A. Scolex of M. nagasawai; small letters indicate locations of details in $\mathrm{C}-\mathrm{J}$; arrowhead points to primary areola. B. Surface of scolex proper of $M$. nagasawai. C. Distal surface of anterior loculus of M. nagasawai. D. Distal surface of posterior loculus of M. nagasawai. E. Proximal surface posterior loculus of M. nagasawai. F. Distal surface of remus of M. nagasawai. G. Proximal surface of remus of $M$. nagasawai. H. Proximal surface of primary areola of M. nagasawai. I. Rim of remus of M. nagasawai. J. Strobilar surface of M. nagasawai. K. Base of everted cirrus of M. nagasawai. L. Tip of everted cirrus of M. nagasawai. M. Eggs of M. nagasawai. N. Scolex of M. cf. nagasawai; arrowheads point to primary areolae. 
Description. Based on six complete mature worms, one incomplete mature worm, one detached pre-gravid proglottid, five detached gravid proglottids, two cross-section series of mature proglottids, two scolices and one detached gravid proglottid examined with SEM, and one egg preparation.

Worms euapolytic, slightly craspedote, $16.6-24.3(20.0 \pm 2.8 ; 6) \mathrm{mm}$ long; proglottids $90-118(99 \pm 11 ; 6)$ in total number; maximum width at level of scolex (Fig. 2E). Scolex 601-1,019 (762 $\pm 171.9 ; 7)$ long, 915-1,299 (1,092 $\pm 123.7 ; 7)$ wide, consisting of four acetabula and cephalic peduncle. Scolex proper 367-405 $(390 \pm 15.5 ; 5)$ wide. Acetabulum bothridiate in form, $255-374(324 \pm 41.7 ; 6$; 12) long, biloculate, sessile anteriorly, free posteriorly; anterior loculus undivided, 98-163 (134 $\pm 18.3 ; 7$; 14) long, $130-216(164 \pm 31.1 ; 7 ; 14)$ wide, without posterolateral extensions; posterior loculus undivided, 156-226 (196 $\pm 24.9 ; 6$; 12) long, 135-201 (164 \pm 19.6 ; 6; 11) wide. Cephalic peduncle bearing four stalked remi (Figs. 2D, 5A); region between bothridia and remi, and region posterior or remi short; stalk 62-179 $(116 \pm 30.7 ; 6 ; 12)$ long, $144-234(183 \pm 28.5 ; 6 ; 11)$ wide; remus without stalk, weakly folded, slightly longer than wide, 455-880 (597 \pm 185.6 ; 4; 6) long, 386-610 (494 $\pm 71.1 ; 6$; 11) wide, tapering terminally, with terminal primary areola and inconspicuous subterminal secondary areola; primary areola 48-65 (56 $\pm 5.5 ; 6$; 11) long, 84-125 (105 $\pm 14.3 ; 6$; 11) wide. Neck absent.

Apex of scolex proper (Fig. 5B), distal surface of anterior loculus (Fig. 5C) and posterior loculus (Fig. 5D), proximal surface of anterior loculus and posterior loculus (Fig. 5E), distal (Fig. 5F) and proximal (Fig. 5G) surfaces of remus, and distal surface of primary areola covered with slender gladiate spinitriches and capilliform filitriches of varying densities; proximal surface of primary areola (Fig. $5 \mathrm{H}$ ) covered with slender gladiate spinitriches and shorter capilliform filitriches; filitriches on rims of bothridia and remi conspicuous (Fig. 5I). Strobila covered with capilliform filitriches (Fig. 5J).

Immature proglottids wider than long, becoming approx. as long as wide with maturity (Fig. 2E), 76-111 (89 $\pm 14 ; 6)$ in number; terminal immature proglottid 552-628 (601 $\pm 27.2 ; 6)$ long, 482-670 (567 $\pm 74.6 ; 6)$ wide. Mature proglottids becoming longer than wide posteriorly (Fig. 2F), 5-12 $(8 \pm 2 ; 6)$ in number; terminal proglottid 966-1,707 (1,257 $\pm 279.3 ; 6)$ long, 477-682 $(586 \pm 85.5 ; 6)$ wide, length to width ratio 1.6-3.6 (2.2 $\pm 0.7 ; 6): 1$. Detached gravid proglottids 2,406-3,629 $(2,805 \pm 483.6$; 5) long, 1,000-1,242 (1,110 $\pm 117.0 ; 5)$ wide. Testes in field extending from anterior margin of proglottid to ovarian bridge, arranged in multiple columns, one irregular layer deep in cross section (Fig. 6A), 131-224 $(177 \pm 28 ; 6 ; 18)$ in total number, $28-50(38 \pm 7 ; 6 ; 18)$ in number in post-poral field, $21-49(34 \pm 7.9 ; 6 ; 18)$ long, $38-90(57 \pm 15.1 ; 6 ; 8)$ wide. Vas deferens coiled, essentially medial to cirrus sac. Cirrus sac pyriform, 204-260 (228 $\pm 20.5 ; 6)$ long, 102-155 (117 $\pm 19.3 ;$; $)$ wide, thin-walled, containing coiled cirrus; cirrus armed with coniform spinitriches and capilliform filitriches (Fig. 5L), spinitriches denser at base (Fig. $5 \mathrm{~K}), 77-88(\mathrm{n}=2)$ wide at base, at least $158 \mathrm{long}(\mathrm{n}=1)$. Genital pores irregularly alternating, 57-62\% (59 \pm 2.1 ; 6) of proglottid length from posterior end; genital atrium shallow. Vagina weakly sinuous, extending from ootype along midline of proglottid, opening into common genital atrium anterior to cirrus sac. Ovary at posterior margin of proglottid, H-shaped in frontal view, 173-337 $(221 \pm 65.8 ; 6)$ long, 186-405 (324 $\pm 73.5 ; 6)$ wide, tetralobed in cross section (Fig. 6B); ovarian margins lobulated. Vitellarium follicular; follicles 7-20 $(12 \pm 3.7$; 6; 18) long, $16-53(31 \pm 10.1 ; 6 ; 18)$ wide, arranged in two lateral bands; each band consisting of multiple irregular columns of follicles, encroaching in midline of proglottid, extending throughout length of proglottid, interrupted by terminal genitalia, uninterrupted by ovary. Uterus ventral (Fig. 6A), medial, extending from ootype region to level of cirrus sac; uterine duct sinuous, entering uterus approximately at midpoint. Excretory vessels four, arranged in one dorsal and one ventral pair on each lateral margin of proglottid. Eggs spherical (Figs. 5M, 6C), single, 18-23 (21 \pm 1.4 ; 18 ) in diameter.

Remarks. This new species differs from M. chongi, M. gambangi, M. limae, and M. myliobatidis in that its remi are wider than long, rather than longer than wide. It is also a much larger worm than all four of these species (16.6-24.3 vs. 1.4-1.8, 1.1-2.1, 2.4-5, 1.4-3.4 mm in TL, respectively). The remi of M. nagasawai $\mathbf{n}$. sp. are weakly folded, rather than highly folded and voluminous, as seen in $M$. narinari and, whereas the remi of $M$. narinari taper conspicuously posteriorly, those of $M$. nagasawai $\mathbf{n}$. sp. are wider and more bluntly rounded at their posterior-most point. This new species most closely resembles $M$. rubrum in that its remi are both wider than long and weakly folded. It conspicuously differs from the latter species in that it is substantially shorter in total length (4.6-24.3 vs. $80 \mathrm{~mm}$ ).

Specimens of M. nagasawai n. sp. from its type host, Aetob. narutobiei, off Japan, fixed in ethanol for molecular work were not available for study. Two specimens taken from the type host in the Gulf of Tonkin off Viet Nam were included in our phylogenetic analysis. Although the scolex morphology of the more than 25 specimens from 
two host specimens from Viet Nam was highly consistent with that of specimens from Japan (Fig. 5N vs. 5A), the strobila of specimens from Viet Nam was much more delicate and smaller than that of the specimens from Japan. However, the specimens from Viet Nam were also all immature. We have referred to these specimens as $M$. cf. $n a-$ gasawai until mature worms from Viet Nam can be examined and their identity confirmed. The strobila voucher of the scolex of the specimens from Viet Nam examined with SEM was deposited in the LRP (LRP no. 10367).

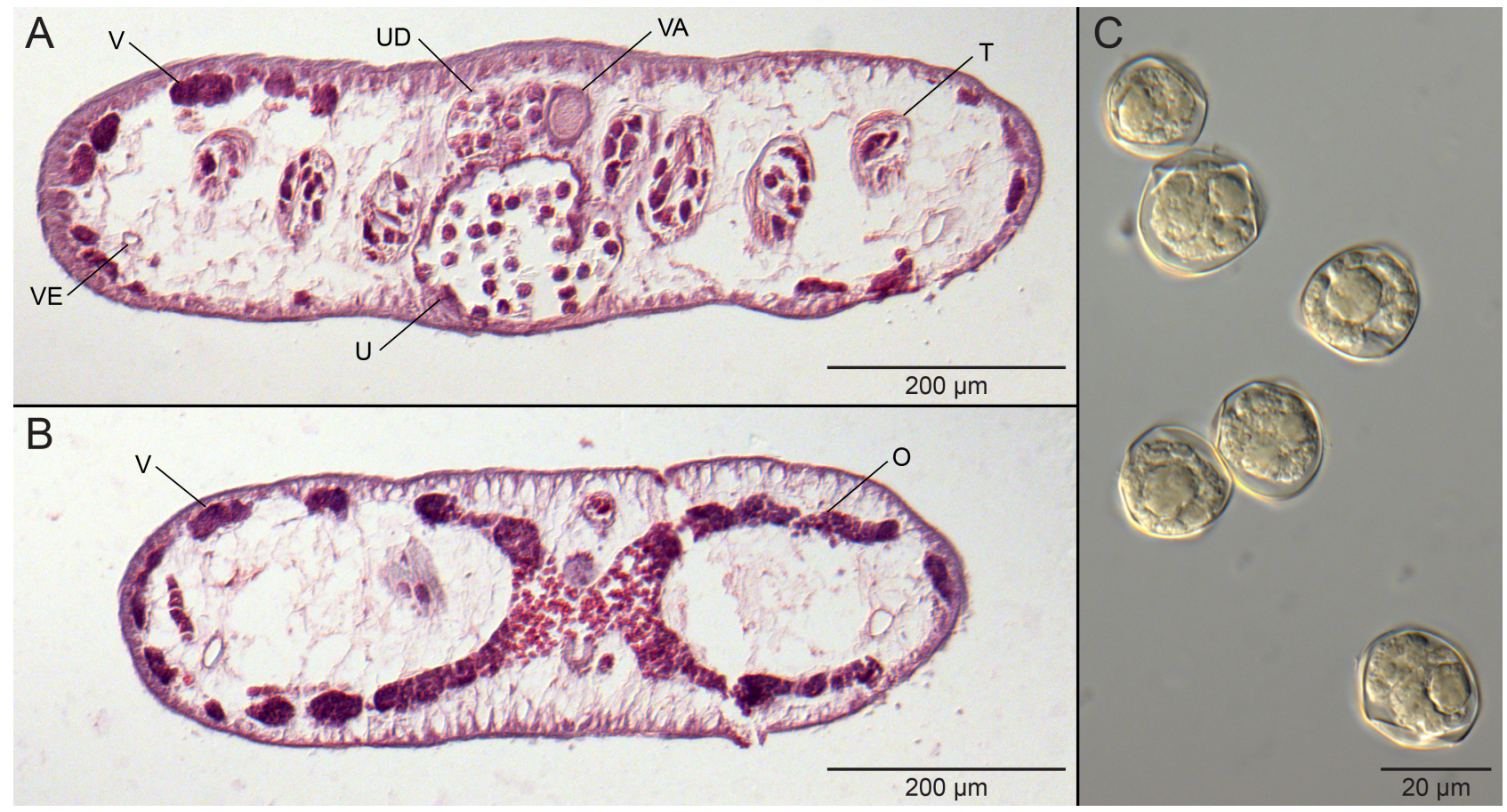

FIGURE 6. Photomicrographs of histological sections of Myzophyllobothrium nagasawai n. sp. from Aetobatus narutobiei from Japan. A. Cross section through detached gravid proglottid between cirrus sac and ovary. B. Cross section through mature proglottid at level of ovarian bridge. C. Eggs. Abbreviations: O, ovary; T, testes; U, uterus; UD, uterine duct; V, vitelline follicles; VA, vagina; VE, ventral excretory vessel.

\section{Discussion}

The taxonomic actions taken here to achieve generic monophyly have reduced the number of genera in the family Rhoptrobothriidae from four to one, rendering the family monogeneric. Nonetheless, the bizarre morphology of the members of this genus relative to the other groups of phyllobothriideans, and in particular their possession of remi extending from the cephalic peduncle, seems sufficient to justify retaining their family status. It also seems likely that additional diversity in this group remains to be discovered in the members of the genera Aetobatus and Aetomylaeus that have not yet been examined for cestodes.

We remain puzzled about the rhoptrobothriid specimen from the zebra shark, Stegostoma fasciatum (Orectolobiformes), included in the molecular phylogenetic analysis of Caira et al. (2014). In preparing this manuscript we returned to the cestodes we collected from the spiral intestine of that zebra shark specimen (BO-492) and found several additional specimens of this same rhoptrobothriid species. Based on examination of those specimens and the voucher (LRP no. 8338) of the specimen sequenced by Caira et al. (2014) we have revised the identification of these specimens from Rhoptrobothrium cf. gambangi to Myzophyllobothrium limae. Their presence in a shark of this order - given the type host is Aetom. nichofii collected from that same locality — is puzzling given that we did not find them in any of the other four zebra shark specimens we examined from Borneo, nor have they previously been reported from zebra sharks (Hornell 1912; Khambata and Bal 1954; Yamaguti 1954; Beveridge and Justine 2007). The fact that none of these cestode specimens were fully mature leads us to suspect this may be a case of accidental infection.

Given the proglottid anatomy of the rhoptrobothriids most closely resembles that of a number of phyllobothriid genera, distinguishing Myzophyllobothrium from other phyllobothriidean genera in the Remarks section above 
seemed appropriate. However, there remains some uncertainty regarding the affinities of Myzophyllobothrium relative to other tetrabothridiate genera hosted by elasmobranchs. As a consequence, the ordinal placement of Myzophyllobothrium is also uncertain. Historically, its species have been considered members of the family Phyllobothriidae within the order Tetraphyllidea (e.g., Southwell 1925; Wardle and McLeod 1952; Schmidt 1986; Euzet 1994; Jensen and Caira 2006). However, when Caira et al. (2014) established the new order Phyllobothriidea, these genera were retained at least temporarily in the non-monophyletic "Tetraphyllidea" because the two representatives included in their analyses (referred to as Rhoptrobothrium cf. gambangi and Myzocephalus sp. 1) failed to group with the Phyllobothriidea. Caira et al. (2017) subsequently erected the family Rhoptrobothriidae Caira, Jensen, and Ruhnke, 2017 within the "Tetraphyllidea" to house these genera noting that while the group appears to be highly supported, its affinities relative to other "tetraphyllidean" clades are unclear. Based on Article 40.1 of the ICZN (pg. 46; ICZN, 1999), which states that "when the name of a type genus of a nominal family-group taxon is considered to be a junior synonym of the name of another nominal genus, the family-group name is not to be replaced on that account alone" the family name Rhoptrobothriidae is retained for this clade. Although the two representatives of Myzophyllobothrium included by Caira et al. (2014) grouped away from the Phyllobothriidea, neither the node of the clade assigned to the Phyllobothriidea nor the node grouping the representatives of Myzophyllobothrium with other elasmobranchhosted genera was well supported. As a consequence, the ordinal affinities of this genus remain unclear.

\section{Acknowledgments}

We are grateful to Kazuya Nagasawa for providing the specimens of Myzophyllobothrium nagasawai from Japan. We thank Daniel Fernando, Akshay Tanna, Rosalind Bown, and Ramajeyam Gobiraj of Blue Resources Trust for logistical support during our fieldwork in Sri Lanka. We are grateful to the Tokyo Cement Group for institutional support to the Blue Resources Trust. The collections in Viet Nam would not have been possible without the expert logistical assistance of Binh Tran Thi and Nguyen Van Ha. We thank Joanna Cielocha, Claire Healy, and Maria Pickering for assisting with the fieldwork in Viet Nam. We are very grateful to local fishers for host specimen collections, Albert Gambang, Annie Lim, Fahmi, and Dharmadi for in-country logistical support, and to Loren Caira, Claire Healy, and Gavin Naylor for assistance with fieldwork in Borneo. We are also grateful to Hannah Ralicki, Elizabeth Jockusch, and Kaylee Herzog for generating the $28 \mathrm{~S}$ sequence data for the eight specimens included in our phylogenetic analysis. Kendra Mojica prepared the sections of the detached gravid proglottid of the new species. Noraida Martínez-Rivera, of the Microscopy and Analytical Imaging Research Resource Laboratory at the University of Kansas, and Kaylee Herzog provided valuable SEM assistance. Collections from Malaysian Borneo were conducted under collecting permit No. UPE:40/200/19SJ.924 from the Economic Planning Unit in Kuala Lumpur and research agreement No. SBC-RA-0050-JNC from the Sarawak Biodiversity Center in Kuching. Collections in Indonesian Borneo (Kalimantan) were conducted under permit Nos. 06253/SU/KS/2006 and 3861/SU.3/KS/2007 from LIPI in Jakarta. Collections in Sri Lanka were conducted under a letter of no objection (as species are not protected under national law and are from dead fisheries specimens) with reference number WL/3/2/74/17, dated 4th January 2018, issued by the Department of Wildlife Conservation, Sri Lanka. Samples were exported from Sri Lanka under a letter of no objection with reference number WL/3/2/74/17, dated 14th March 2018, issued by the Department of Wildlife Conservation, Sri Lanka. This work was supported with funds from National Science Foundation awards DEB Nos. 0818696, 0818823, 1921404, and 1921411, and DBI No. 1560139. Any opinions, findings, conclusions, or recommendations expressed are those of the authors and do not reflect the views of the National Science Foundation.

\section{References}

Baer, J.G. \& Euzet, L. (1962) Revision critique des cestodes tétraphyllides décrits par T. Southwell (1 $1^{\text {re }}$ partie). Bulletin de la Societe Neuchateloise des Sciences Naturelles, 85, 143-172.

Beveridge, I. (1990) Taxonomic revision of Australian Eutetrarhynchidae Guiart (Cestoda: Trypanorhyncha). Invertebrate Taxonomy, 4, 785-845.

https://doi.org/10.1071/IT9900785

Beveridge, I. \& Justine, J.L. (2007) Pseudolacistorhynchus nanus n. sp. (Cestoda: Trypanorhyncha) parasitic in the spiral valve 
of the zebra shark, Stegostoma fasciatum (Hermann, 1783). Transactions of the Royal Society of South Australia, 131, 175-181. https://doi.org/10.1080/03721426.2007.10887081

Caira, J.N., Bueno, V. \& Jensen, K. (2021) Emerging global novelty in phyllobothriidean tapeworms (Cestoda: Phyllobothriidea) from sharks and skates (Elasmobranchii). Zoological Journal of the Linnean Society, zlaa185. https://doi.org/10.1093/zoolinnean/zlaa185

Caira, J.N., Jensen, K. \& Barbeau, E. (2020a) Global Cestode Database. Available from: http://www.elasmobranchs.tapewormdb.uconn.edu (accessed 10 January 2021)

Caira, J.N., Jensen, K., Hayes, C. \& Ruhnke, T.R. (2020c) Insights from new cestodes of the crocodile shark, Pseudocarcharias kamoharai (Lamniformes: Pseudocarchariidae), prompt expansion of Scyphyophyllidium and formal synonymization of seven phyllobothriidean genera — at last! Journal of Helminthology, 94, e132. https://doi.org/10.1017/S0022149X20000036

Caira, J.N., Jensen, K. \& Healy, C.J. (1999) On the phylogenetic relationships among tetraphyllidean, lecanicephalidean and diphyllidean tapeworm genera. Systematic Parasitology, 42, 77-151. https://doi.org/10.1023/a:1006192603349

Caira, J.N., Jensen, K. \& Healy, C.J. (2001) Interrelationships among Tetraphyllidean and Lecanicephalidean cestodes. In: Littlewood, D.T.J. \& Bray, R.A. (Eds.), Interrelationships of the Platyhelminthes. Taylor \& Francis, London, pp. $135-158$.

Caira, J.N., Jensen, K., Pickering, M., Ruhnke, T.R. \& Gallagher, K.A. (2020b) Intrigue surrounding the life-cycles of species of Clistobothrium (Cestoda: Phyllobothriidea) parasitising large pelagic sharks. International Journal for Parasitology, 50, 1043-1055. https://doi.org/10.1016/j.ijpara.2020.08.002

Caira, J.N., Jensen, K. \& Ruhnke, T.R. (2017) “Tetraphyllidea” van Beneden, 1849 relics. In: Caira, J.N. \& Jensen, K. (Eds.), Planetary Biodiversity Inventory (2008-2017): Tapeworms from Vertebrate Bowels of the Earth. University of Kansas, Natural History Museum, Special Publication No. 25. University of Kansas, Natural History Museum, Lawrence, Kansas, pp. 371-400.

Caira, J.N., Jensen, K., Waeschenbach, A., Olson, P.D. \& Littlewood, D.T.J. (2014) Orders out of chaos-molecular phylogenetics reveals the complexity of shark and stingray tapeworm relationships. International Journal for Parasitology, 44, 55-73. https://doi.org/10.1016/j.ijpara.2013.10.004

Campbell, R.A. \& Beveridge, I. (2002) The genus Acanthobothrium (Cestoda: Tetraphyllidea: Onchobothriidae) parasitic in Australian elasmobranch fishes. Invertebrate Systematics, 16, 237-344. https://doi.org/10.1071/it01004

Chervy, L. (2009) Unified terminology for cestode microtriches: A proposal from the International Workshops on Cestode Systematics in 2002-2008. Folia Parasitologica, 56, 199-230. https://doi.org/10.14411/fp.2009.025

Coleman, G.M., Beveridge, I. \& Campbell, R.A. (2019) Caulobothrium pedunculatum sp. nov., a new species of cestode (Platyhelminthes) parasitic in Australian stingrays (Elasmobranchii: Batoidea). Transactions of the Royal Society of South Australia, 143, 167-174. https://doi.org/10.1080/03721426.2019.1624932

Darriba, D., Taboada, G.L., Doallo, R. \& Posada, D. (2012) jModelTest 2: more models, new heuristics and parallel computing. Nature Methods, 9, 772 . https://doi.org/10.1038/nmeth.2109

Deshmukh, R.A. (1979) On three new species of Uncibilocularis Southwell, 1925 (Cestoda: Onchobothriidae) from marine fishes with a key to the species of the genus. Proceedings of the National Academy of Sciences, India, 49 (B), $227-236$.

Deshmukh, R.A. \& Shinde, G.B. (1979) Three new species of Tetragonocephalum Shipley and Hornell, 1905 (Cestoda: Tetragonocephalidae) from marine fishes of west coast of India. Bioresearch, 3, 19-23.

Euzet, L. (1994) Order Tetraphyllidea Carus, 1863. In: Khalil, L.F., Jones, A. \& Bray, R.A. (Eds.), Keys to the Cestode Parasites of Vertebrates. CAB International, Wallingford, pp. 149-194.

Fernando, D., Bown, R.M.K., Tanna, A., Gobiraj, R., Ralicki, H., Jockusch, E.L., Ebert, D.A., Jensen, K. \& Caira, J.N. (2019) New insights into the identities of the elasmobranch fauna of Sri Lanka. Zootaxa, 4585 (2), 201-238. https://doi.org/10.11646/zootaxa.4585.2.1

Guindon, S. \& Gascuel, O. (2003) A simple, fast, and accurate algorithm to estimate large phylogenies by maximum likelihood. Systematic Biology, 52, 696-704. https://doi.org/10.1080/10635150390235520

Hahn, C., Bachmann, L. \& Chevreux, B. (2013) Reconstructing mitochondrial genomes directly from genomic next-generation sequencing reads - a baiting and iterative mapping approach. Nucleic Acids Research, 41, e129. https://doi.org/10.1093/nar/gkt371

Haseli, M. (2013) Trypanorhynch cestodes from elasmobranchs from the Gulf of Oman, with the description of Prochristianella garshaspi n. sp. (Eutetrarhynchidae). Systematic Parasitology, 85, 271-279. https://doi.org/10.1007/s11230-013-9425-8

Haseli, M. \& Palm, H.W. (2015) Dollfusiella qeshmiensis n. sp (Cestoda: Trypanorhyncha) from the cowtail stingray Pastina- 
chus sephen (Forsskål) in the Persian Gulf, with a key to the species of Dollfusiella Campbell \& Beveridge, 1994. Systematic Parasitology, 92, 161-169.

https://doi.org/10.1007/s11230-015-9592-x

Hassan, S.H. (1983) Acanthobothrium manteri sp. n. a tetraphyllidean cestode (Oncobothriidae [sic]) from Dasyatis sephen. Journal of the Egyptian Society of Parasitology, 13, 75-80.

Hornell, J. (1912) New cestodes from Indian fishes. Records of the Indian Museum, 7, 197-204.

ICZN. (1999) International Code of Zoological Nomenclature, 4th edition. The International Trust for Zoological Nomenclature, London, $306 \mathrm{pp}$.

Jensen, K. \& Caira, J.N. (2006) The status of Rhoptrobothrium Shipley et Hornell, 1906 (Cestoda: Tetraphyllidea), with redescription of the type species, $R$. myliobatidis, and description of three new species from two species of Aetomylaeus (Myliobatiformes: Myliobatidae) from Malaysian Borneo. Folia Parasitologica, 53, 189-207. https://doi.org/10.14411/fp.2006.025

Jensen, K. \& Caira, J.N. (2008) A revision of Uncibilocularis Southwell, 1925 (Tetraphyllidea: Onchobothriidae) with the description of four new species. Comparative Parasitology, 75, 157-173. https://doi.org/10.1654/4347.1

Joyeux, C. \& Baer, J.G. (1961) Classe de Cestodes. Cestoidea Rudolphi. In: Baer, J.-G., de Beauchamp, P., Caullery, M., Euzet, L., Gontcharoff, M., Grass, P.-P. \& Joyeux, C. (Eds.), Trait de Zoologie. Anatomie, systématique, biologie. Tome IV. Plathelminthes, Mésozoaires, Acanthocéphales, Némertiens. Masson et Cie, Paris, pp. 347-560.

Khambata, F.S. \& Bal, D.V. (1954) Studies on the cestodes of marine fishes from Bombay. Part I - On the genus Balanobothrium Hornell, 1912 (Cestoda), with a description of a new species. Journal of the Zoological Society of India, 6, 101-110.

Kuchta, R. \& Caira, J.N. (2010) Three new species of Echinobothrium (Cestoda: Diphyllidea) from Indo-Pacific stingrays of the genus Pastinachus (Rajiformes: Dasyatidae). Folia Parasitologica, 57, 185-196. https://doi.org/10.14411/fp.2010.025

Last, P.R., White, W.T., de Carvalho, M.R., Séret, B., Stehmann, M.F.W. \& Naylor, G.J.P. (2016) Rays of the World. Cornell University Press, Ithaca, New York, 790 pp.

Linton, E. (1892) The anatomy of Thysanocephalum crispum, Linton, a parasite of the tiger shark. Report of the United States Commissioner of Fish and Fisheries for 1888, 1892, 543-556.

Löytynoja, A. \& Goldman, N. (2010) webPRANK: a phylogeny-aware multiple sequence aligner with interactive alignment browser. BMC Bioinformatics, 11, 579. https://doi.org/10.1186/1471-2105-11-579

Maleki, L., Malek, M. \& Palm, H.W. (2013) Two new species of Acanthobothrium (Tetraphyllidea: Onchobothriidae) from Pastinachus cf. sephen (Myliobatiformes: Dasyatidae) from the Persian Gulf and Gulf of Oman. Folia Parasitologica, 60, 448-456. https://doi.org/10.14411/fp.2013.048

Maleki, L., Malek, M. \& Rastgoo, A. (2018) Acanthobothrium chabahariensis n. sp. (Cestoda: Onchoproteocephalidea) in the cowtail stingray Pastinachus cf. sephen (Myliobatiformes: Dasyatidae) from the Gulf of Oman, Iran. Journal of Genetic Resources, 4, 114-121. https://doi.org/10.22080/jgr.2019.15565.1120

Naylor, G.J.P., Caira, J.N., Jensen, K., Rosana, K.A.M., White, W.T. \& Last, P.R. (2012) A DNA sequence-based approach to the identification of shark and ray species and its implications for global elasmobranch diversity and parasitology. Bulletin of the American Museum of Natural History, 367, 1-262. https://doi.org/10.1206/754.1

Olson, P.D., Cribb, T.H., Tkach, V.V., Bray, R.A. \& Littlewood, D.T. (2003) Phylogeny and classification of the Digenea (Platyhelminthes: Trematoda). International Journal for Parasitology, 33, 733-755. https://doi.org/10.1016/s0020-7519(03)00049-3

Pleijel, F., Jondelius, U., Norlinder, E., Nygren, A., Oxelman, B., Schander, C., Sundberg, P. \& Thollesson, M. (2008) Phylogenies without roots? A plea for the use of vouchers in molecular phylogenetic studies. Molecular Phylogenetics and Evolution, 48, 369-371. https://doi.org/10.1016/j.ympev.2008.03.024

Reyda, F., Healy, C., Haslach, A., Ruhnke, T., Aprill, T., Bergman, M., Daigler, A., Dedrick, E., Delgado, I., Forti, K., Herzog, K., Russell, R. \& Willsey, D. (2016) A new genus of rhinebothriidean cestodes from batoid elasmobranchs, with the description of five new species and two new combinations. Folia Parasitologica, 63, 038. https://doi.org/10.14411/fp.2016.038

Roohi Aminjan, A. \& Malek, M. (2017) Two new species of Tetragonocephalum (Cestoda: Lecanicephalidea) from Pastinachus sephen (Myliobatiformes: Dasyatidae) from the Gulf of Oman. Folia Parasitologica, 64, 014. https://doi.org/10.14411/fp.2017.014

Ruhnke, T.R., Caira, J.N. \& Pickering, M. (2017) Phyllobothriidea Caira, Jensen, Waeschenbach, Olson \& Littlewood, 2014. In: Caira, J.N. \& Jensen, K. (Eds.), Planetary Biodiversity Inventory (2008-2017): Tapeworms from Vertebrate Bowels of the Earth. University of Kansas, Natural History Museum, Special Publication No. 25. University of Kansas, Natural History Museum, Lawrence, Kansas, pp. 305-326.

Schaeffner, B.C. \& Beveridge, I. (2012) Description of a new trypanorhynch species (Cestoda) from Indonesian Borneo, with the 
suppression of Oncomegoides and the erection of a new genus Hispidorhynchus. Journal of Parasitology, 98, 408-414. https://doi.org/10.1645/GE-2859.1

Schaeffner, B.C. \& Beveridge, I. (2013) Dollfusiella Campbell \& Beveridge, 1994 (Trypanorhyncha: Eutetrarhynchidae) from elasmobranchs off Borneo, including descriptions of five new species. Systematic Parasitology, 86, 1-31. https://doi.org/10.1007/s11230-013-9435-6

Schmidt, G.D. (1986) CRC Handbook of Tapeworm Identification. CRC Press Inc., Boca Raton, Florida, 675 pp.

Shinde, G.B. \& Chincholikar, L.N. (1980) Mixophyllobothrium okamuri gen. nov. sp. nov. (Cestoda: Tetraphyllida) from Trygon sephen at Ratnagiri, India. Rivista di Parassitologia, 41, 413-417.

Shinde, G.B. \& Deshmukh, R.A. (1979) On a new species of Flapocephalus Deshmukh R. A., 1977 (Cestoda: Lecanicephalidae Braun, 1900) from a marine fish at Veraval, west coast of India. Rivista di Parassitologia, 40, 295-298.

Shipley, A.E. \& Hornell, J. (1906) Report on the cestode and nematode parasites from the marine fishes of Ceylon. Report to the Government of Ceylon on the Pearl Oyster Fisheries of the Gulf of Manaar (Herdman), Part V, 43-96.

Southwell, T. (1925) A monograph on the Tetraphyllidea with notes on related cestodes. Memoirs of the Liverpool School of Tropical Medicine, New Series, 2, 1-368.

Southwell, T. (1929) A monograph on cestodes of the order Trypanorhyncha from Ceylon and India. Part I. Ceylon Journal of Science, Section B, Zoology and Geology, 15, 169-312.

Tkach, V.V., Littlewood, D.T.J., Olson, P.D., Kinsella, J.M. \& Swiderski, Z. (2003) Molecular phylogenetic analysis of the Microphalloidea Ward, 1901 (Trematoda: Digenea). Systematic Parasitology, 56, 1-15. https://doi.org/10.1023/A:1025546001611

Van der Auwera, G., Chapelle, S. \& De Wachter, R. (1994) Structure of the large ribosomal subunit RNA of Phytophthora megasperma, and phylogeny of the oomycetes. FEBS Letters, 338, 133-136. https://doi.org/10.1016/0014-5793(94)80350-1

Verma, S.C. (1928) Some cestodes from Indian fishes, including four new species of Tetraphyllidea and revised keys to the genera Acanthobothrium and Gangesia. Allahabad University Studies, 4, 119-176.

Wardle, R.A. \& McLeod, J.A. (1952) The Zoology of Tapeworms. University of Minnesota Press, Minneapolis, Minnesota, 780 pp.

Yamaguti, S. (1954) Parasitic worms mainly from Celebes. Part 6. Cestodes of fishes. Acta Medicinae Okayama, 8, 353-374.

Yamaguti, S. (1959) Systema Helminthum. Volume II. The Cestodes of Vertebrates. Interscience Publishers, Inc., New York, New York, 860 pp.

Zschoche, M., Caira, J.N. \& Fyler, C.A. (2011) A new species of Acanthobothrium van Beneden, 1850 (Tetraphyllidea: Onchobothriidae) from Pastinachus atrus (Macleay) (Batoidea: Dasyatidae) in Australian waters, with a reassessment of the host associations of Acanthobothrium spp. parasitising Pastinachus spp. Systematic Parasitology, 78, 109-116. https://doi.org/10.1007/s11230-010-9279-2 